Received : August 13, 2021

Accepted : August 16, 2021

Published : October 13, 2021
Homepage: http://trj.stptrisakti.ac.id/index.php/trj/index

DOI: https://doi.org/10.30647/tri.v5i2.126

Tourism Research Journal

E-ISSN: 2598-9839

2021, Vol. 5 No. 2

\title{
Agrotourism Development Using Location Quotient Analysis in Cibuntu-Kuningan Village
}

\author{
Anita Swantari, Heny Ratnaningtyas*, Filma Festivalia \\ Trisakti School of Tourism \\ *heny.ratnaningtyas@stptrisakti.ac.id
}

\begin{abstract}
Cibuntu Village is a sub-district area that is one of the villages that has the potential for the development of the agricultural, plantation, and livestock sectors. In addition to these sectors, the tourism sector with the concept of agrotourism is expected to be developed and will make a significant contribution to the economy in Cibuntu Village. The purpose of this study is to determine the location of tourist attractions in Cibuntu Village and determine the types of tourism that can be developed in that location. The data analysis method used is divided into two parts, namely policy analysis and basic sector analysis using LQ (Location Quotient) calculation analysis. With applicable policy restrictions, tourism activities in Cibuntu Village are agrotourism and ecotourism. From the results of the LQ calculation, there are superior commodities, namely sweet potatoes, these commodities are worthy of investment to be developed in the future. Several alternative locations for tourism objects and activities that can be developed are agro-tourism activities in agricultural areas located in Cibuntu village which are designated as ecotourism areas.
\end{abstract}

Keywords: Cibuntu Village Kuningan, Agrotourism, Location Quotient 
Agrotourism Development Using Lacotion Quotient Analysis in Cibuntu-Kuningan Village

\section{A. Introduction}

Cibuntu village which is an area of Pasawahan Subdistrict, Kuningan Regency, has an area of 1,078,741 ha with a population in 2021 of 1,000 people is one of the villages that have the potential for the development of agriculture, plantations, and livestock sectors. Cibuntu Kuningan Tourism Village has natural tourism, historical and cultural tourism. This village is also one of the best community-based tourism villages in Indonesia. The community offers beautiful natural beauty. Historical tourism in this village is characterized by several sites relics of the Stone age (Megalithic), one of which is a statue of historical relics of the Hindu Buddhist period called the sites saurip Kidul, Bujal Dayeuh, and Hulu Dayeuh. In addition there are also Birit Dayeuh sites and Cikahuripan Sites (Alfatianda \& Djuwendah, 2017).

With the development of these sectors, the infrastructure supporting its activities will also increase. The increase in the activities of these sectors is expected to improve the economy in Cibuntu Village. In addition to the above sectors, there is also one sector that is expected to be developed and will have a significant contribution to the economy in Cibuntu Village, namely the tourism sector, more precisely agrotourism, because of the background of Cibuntu Village which is an agrarian village (Artina et al, 2018).

The tourism sector, especially agrotourism which is one of the sectors that can improve the economy in Cibuntu Village which is not currently optimized for potential, so there needs to be a study that can determine potential locations to be developed into agrotourism areas (Bafdal et al, 2014).

Tourism is the potential to be developed, moreover, it is supported by the natural resources in Cibuntu Village which are supported by agriculture, especially fruit crops. Mango, jackfruit, coffee, sweet potato, and banana are commodities that have a high amount of production compared to other commodities in Cibuntu Village. Agrotourism development is inseparable from the role of the community in managing their natural resources so that they have an attraction for tourists, both local and foreign. This superior commodity in Cibuntu Village is expected to be developed in special agro-tourism areas and there is an increase in added value from agro-tourism so that it can contribute more to improving the economy of Kuningan Regency. Not only from the agricultural sector but also from the tourism or agro-tourism sector. This study aims to determine the area of agro-tourism development based on superior commodities in Cibuntu Village (Institut Pertanian Bogor, 2017).

Various approaches and analytical tools have been widely used to identify leading commodities with a more robust economic development tool with all its advantages and limitations. The analysis used is Location Quetiont. According to Bappenas, LQ is a method to calculate the relative comparison of the contribution of the added value of a sector in a region (district/city) to the added value of the sector on the province or national scale. This technique is usually

Tourism Research Journal, Volume 5 (2), 2021 
Agrotourism Development Using Lacotion Quotient Analysis in Cibuntu-Kuningan Village

used to identify the sectors of the flagship economic sector (base) that have the potential to be developed (Faidah et al, 2016).

\section{B. Literature Review}

\section{Agrotourism}

Agrotourism is a series of travel activities that utilize the location or agricultural sector from the beginning of production to obtain agricultural products in various systems and scales to expand, knowledge, understanding, experience, and recreation in the field of farming (Indrawati et al, 2020). This shows that agrotourism not only offers agricultural products to visitors but also offers services to make visitors feel satisfied and entertained and can even have the ability to better understand the agricultural sector (Indrayanti et al, 2020).

Agrotourism is a concept and is a new product for tourism that can be used as alternative tourism and as an alternative step in neutralizing the impact of tourism activities (Arismayanti et al, 2019). Agrotourism is alternative tourism that utilizes natural resources in its activities, agrotourism also serves as an educational tourism provider services that provide an understanding of the process of farming ranging from planting, care, harvesting even to marketing and processing to increase the added value of existing resources and able to increase the income of farmers (Budiasa \& Ambarawati, 2014).

\section{Location Quotient (LQ)}

Location Quotient (LQ) is a comparison of the role of a sector/industry in a region to the size of the role of the sector/industry nationally (Isabhandia \& Setiartiti, 2021). The sector/industry compared in the region should be the same as the national sector/industry and the comparison time should also be the same. Static Location Quotient (SLQ) analysis is a preliminary analysis to determine the advantages of an economic sector in a region (Boedirachminarni et al, 2017). SLQ analysis techniques describe a relative comparison between the capabilities of a sector in an area analyzed with the capabilities of the same sector in the wider area. Variables that can be used as a measure to produce SLQ coefficients can be the number of labor, production value, or other variables (Prats \& Ramirez, 2018).

LQ technique is one of the commonly used approaches in the base economic model as a first step to understanding the sector of activity that triggers growth. LQ measures the relative concentration or degree of specialization of economic activity through a comparative approach (Suarmanayasa et al, 2018). LQ techniques are widely used to discuss economic conditions, leading to the identification of specialization of economic activities or measuring the relative concentration of economic activity to get an overview in the determination of the leading sector as the leading sector of industrial economic activity (2018). 


\section{Potential Cibuntu Village Tourism Objects}

Cibuntu village is a village with mainland use dominated by agriculture and plantations. The condition of the fertile land and located at the foot of Mount Ciremai so that it has a good climate to be a location of agriculture and plantations. Fertile agricultural land and beautiful panoramic views of Mount Ciremai become the main force in the development and development of the tourism sector in Cibuntu Village. In addition to the agricultural land that has developed, the protected forest area that is also located at the foot of Mount Ciremai is one of the potentials that Cibuntu Village has. With these factors, the potential for tourism object development in Cibuntu Village will not be far from the development of agro-free tourism and nature. Based on observations of tourism potential that is feasible and can be developed, among others: (1) Agrowista in agricultural areas; (2) Nature tourism and adventure in the protected forest area of Mount Ciremai (Fadilla \& Aditya, 2019).

With these restrictions, the tourism activities that can be developed in Cibuntu Village are agrotourism, ecotourism, and other natural tourism activities that do not change the pattern of existing space or plan space patterns. Cibuntu village located at the foot of Mount Ceremai has a very beautiful natural panorama, with a very supportive contour to as a vacation location and developed as a natural tourist location. The panorama that can be an attraction is the view towards Mount Ceremai which is very beautiful, and Gongseng Waterfall located in Cibuntu Village (Pramanik \& Widyastuti, 2017).

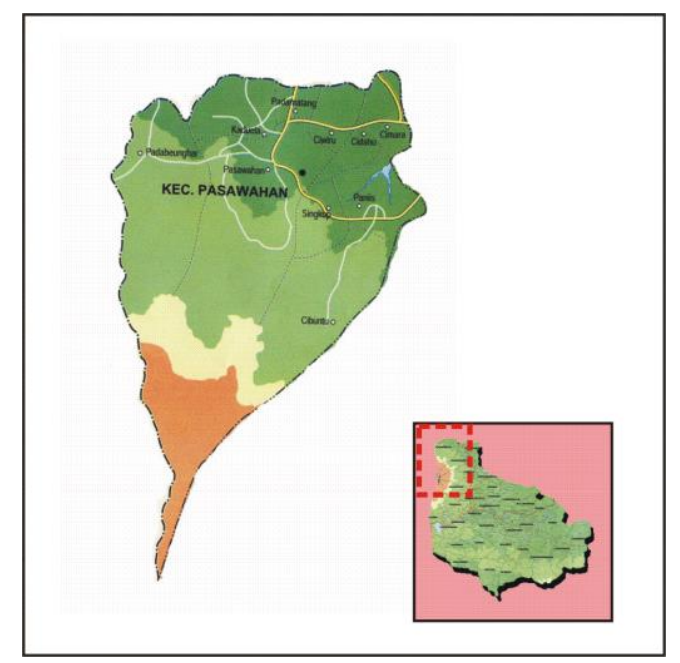

Figure 1. Map of Cibuntu Village

\section{Research Methodology}

The methods used in this study are quantitative methods and analytical methods of determining the location of agrotourism. The data collection method used in this study is divided into two parts, namely observation and literature

Tourism Research Journal, Volume 5 (2), 2021 
studies. While the data analysis method used in this study is divided into two parts, namely base sector analysis, using LQ (Location Quotient) calculation and descriptive analysis of the prevailing policies in Cibuntu Village. The formula for calculating LQ analysis is as follows (Faidah et al, 2016):

Information:

$$
\mathrm{LQs}=(\mathrm{vi} / \mathrm{vt}) /(\mathrm{Vi} / \mathrm{Vt})
$$

LQ : Location Quotient of featured products in Hamlet i Cibuntu Village

vi : Production of superior products (tons) in Hamlet i Cibuntu Village

vt : Total production of superior products (tons) in Hamlet i Cibuntu Villag

$\mathrm{Vi}$ : Production of superior products (tons) in Hamlet i Cibuntu Village

Vt: Total production of superior products (tons) in Hamlet i Cibuntu Village

To find out coefficient localization of superior products in Cibuntu Tourism Village, can use the formula (Setiono, 2011):

Information:

$$
\alpha \mathrm{i}=[\mathrm{Si} / \mathrm{Ni}]-[\Sigma \mathrm{Si} / \Sigma \mathrm{Ni}]
$$

$\alpha \mathrm{i}$ : Localization coefficient, which is positively marked with a value of $0 \leq \alpha$ $\leq 1$

$\mathrm{Si}$ : Production of superior products in Hamlet i Cibuntu Village (tons)

$\mathrm{Ni}$ : Production of wood products in Hamlet i Cibuntu Village (tons)

$\Sigma \mathrm{Si}$ : Total production of superior products in Hamlet i Cibuntu Village (tons)

$\Sigma \mathrm{Ni}$ : Total production of superior products in Hamlet i Cibuntu Village (tons)

\section{Result}

Analysis of leading commodities in Cibuntu Tourism Village, this analysis becomes important to know the superior products in Cibuntu Tourism Village that will be developed as superior products for agrotourism development. The development of this excellent product is very supportive of the program from Kuningan Regency, which makes Cibuntu Tourism Village into an agrotourism and ecotourism village.

Table 1. Number of Production of Superior Products cibuntu Tourism Village

\begin{tabular}{lrrrrrr}
\hline \multicolumn{1}{c}{ Hamlet } & Mango & Jackfruit & $\begin{array}{c}\text { Coffee } \\
\text { Ton }\end{array}$ & Sweet Patato & Banana & Total \\
\hline $\begin{array}{l}\text { Sacatuhu } \\
\text { Hamlet }\end{array}$ & 3,782 & 92 & 198 & 9,524 & 4,324 & $\mathbf{1 7 , 9 2 0}$ \\
\hline $\begin{array}{l}\text { Kahuripan } \\
\text { Hamlet }\end{array}$ & 3,832 & 87 & 196 & 8,259 & 4,780 & $\mathbf{1 7 , 1 5 4}$ \\
\hline $\begin{array}{l}\text { Kuningan } \\
\text { District }\end{array}$ & $\mathbf{6 0 , 3 2 8}$ & $\mathbf{1 2 , 5 9 6}$ & $\mathbf{3 , 9 8 6}$ & $\mathbf{1 1 9 , 2 4 4}$ & $\mathbf{8 0 , 5 2 8}$ & $\mathbf{2 7 6 , 6 8 2}$ \\
\hline
\end{tabular}

Sources: Badan Pusat Statistik Kabupaten Kuningan (2021)

Based on Table 1, showing the number of production of superior products in Sacatuhu and Kahuripan Hamlets, the highest number of production of

Tourism Research Journal, Volume 5 (2), 2021 
Agrotourism Development Using Lacotion Quotient Analysis in Cibuntu-Kuningan Village

superior products in Cibuntu Tourism Village is Sweet Potato in Sacatahu Hamlet of 9,524 tons and Kahuripan Hamlet of 8,259 tons.

Table 2. Location Quotient Number of Production of Superior Products Cibuntu Village

\begin{tabular}{crrrrr}
\hline Hamlet & Mango & Jackfruit & Coffee & Sweet Potato & Banana \\
\hline Sacatuhu Hamlet & 0.97 & 0.11 & 0.77 & 1.23 & 0.83 \\
\hline Kahuripan Hamlet & 0.98 & 0.11 & 0.76 & 1.07 & 0.93 \\
\hline Source
\end{tabular}

Source: Data processed (2020)

Table 3. Localization Coefficient of Number of Production of Cibuntu Tourism Superior Products

\begin{tabular}{lrrrrr}
\hline \multicolumn{1}{c}{ Hamlet } & Mango & Jackfruit & Coffee & Sweet Potato & Banana \\
\hline Sacatuhu Hamlet & -0.0021 & -0.0575 & -0.0151 & 0.0151 & -0.0111 \\
\hline Kahuripan Hamlet & 0.0015 & -0.0051 & -0.0128 & 0.0073 & -0.0026 \\
\hline
\end{tabular}

Source: Data processed (2020)

Based on Table 2, it can be known that the sweet potato commodity of the region that has an LQ value of more than 1 is in Sacatuhu Hamlet of 1.23 and is in Kahuripan Hamlet of 1.07. While in Table 3, it can be known that the localization coefficient value does not reach the value of 1 , but shows a positive value in Sacatuhu Hamlet and Kahuripan Village with localization coefficient values of 0.0151 and 0.0073 .

\section{E. Discussion}

Agricultural agrotourism development in Cibuntu Tourism Village the results of the analysis location quotient of superior products is sweet potatoes because it has a value of LQ more than 1 is in Sacatuhu Hamlet of 1.23 and is in Kahuripan Hamlet of 1.07. Then the localization coefficient value is 0.0151 in Sacatuhu Hamlet and is 0.0073 Kahuripan Hamlet. This means that agricultural activities carried out in Sacatuhu Hamlet and Kahuripan Hamlet have been concentrated on one commodity, namely sweet potato. Agricultural activities are evenly distributed in the hamlets of Sacatuhu and Kahuripan.

Sweet potato is one of the food crop commodities that is one of the mainstays for farmers and local governments. Easy and inexpensive cultivation is one reason to cultivate it. Selling prices and a supportive market make sweet potato production increase from year to year. Sweet potato has a good future potential to meet the production of the food crop sector (Faidah et al, 2016; Abdurahman et al, 2020).

The development of sweet potato commodities is not only to get an abundant amount of production, but it is necessary to pay attention to several aspects. These aspects include regional potential, contribution to regional

Tourism Research Journal, Volume 5 (2), 2021 
income, and contribution to other food crops. These aspects will be a supporting factor for the development of a much better food crop sector, especially sweet potatoes. Commodity development based on commodity type is based on indicators of production and area of land planted for sweet potato cultivation. From there, it will be known which areas have the amount of production and the area of land planted with sweet potatoes which are the basis for sweet potato commodities (Robeta, 2015).

Sweet potato planting in Cibuntu Village applies Plant Growth Promoting Rhizobacteria originating from Mount Ciremai National Park. This plant growthenhancing rhizobacterium was developed from the scarcity of subsidized fertilizers in Cibuntu Village. Mount Ciremai National Park sees this scarcity as an opportunity to make efforts to manage ecosystems in Cibuntu Village which is a buffer village for the National Park by utilizing microbes as a substitute for chemical fertilizers. Bacteria present in plant roots live in colonies around plant roots. For plants, the presence of these microorganisms is very good, because these bacteria provide an advantage in the physiological processes of plants and their growth. Cibuntu residents apply a combination of Plant Growth Promoting Rhizobacteria with manure to support the growth of sweet potatoes (IPB University, 2021).

Farmers in Cibuntu Village are satisfied with the application of Plant Growth Promoting Rhizobacteria to plant sweet potatoes. According to them, the use of Plant Growth Promoting Rhizobacteria can speed up the harvest period by up to one month. It is expected that farmers can consistently use Rhizobacteria and manure as agricultural inputs consistently. The application of Plant Growth Promoting Rhizobacteria can be an effort to maintain the balance of the ecosystem in the buffer village of Mount Ciremai National Park so that it is not damaged by pollution and chemical fertilizer residues (IPB University, 2021).

\section{F. Conclusion}

Based on the results of research and discussion, the development of agrotourism in Cibuntu Village is very good to be done, especially based on the superior products of coffee and sweet potatoes in Sacatuhu and Kahuripan Hamlets. But again adapted to the natural conditions, communities, and the environment around the area that will be developed to be used as an agrotourism development area. Agrotourism development can make the most of natural potential and pay attention to environmental and cultural sustainability 
Agrotourism Development Using Lacotion Quotient Analysis in Cibuntu-Kuningan Village

\section{REFERENCES}

Abdurahman, B., Assagaf, S., \& Achmad. M. J. (2020). Analisis Potensi Wilayah Berbasis Komoditi Pertanian dalam Pembangunan Ekonomi Kota Ternate. Jurnal Ilmiah Agribisnis dan Perikanan (agrikan UMMU-Ternate), 13(2): 201-213.

Alfatianda, C., \& Djuwendah, E. (2017). Dampak Ekowisata Dan Agrowisatav (Eko-Agrowisata) Terhadap Sosial Ekonomi Masyarakat Di Desa Cibuntu (Studi Kasus Di Desa Cibuntu, Kecamatan Pasawahan Kabupaten Kuningan, Jawa Barat). Jurnal Ilmiah Mahasiswa Agroinfo Galuh, 4(1): 434443.

Artina, V., Dewi. W., \& Yulianti, R. (2019). SWOT Analysis of the Development of the Tourist Cibuntu Village, Cibuntu Regency, West Java. IOP Conf. Series: Earth and Environmental Science, 145: 1-10.

Arismayanti, N. K., Sendra, I. M., Suwena, I. K., Budiarsa, M., Bakta, I. M., \& Pitana, I. G. (2019). Tourism Villages' Development in Bali, Mass or Alternative Tourism?. Journal of Tourism and Hospitality Management, 7(2): 117-139.

Bafdal, N., Balia, R. L., Dwiratna, S. \& Amaru, K. (2014). Penyusunan Peta Potensi Desaagrowisata Berbasis Masyarakat Di Desa Cibuntu Kecamatan Pasawahan Kabupaten Kuningan. Dharmakarya: Jurnal Aplikasi Ipteks Untuk Masyarakat, 3(2): 81-87.

Badan Pusat Statistik Kabupaten Kuningan. (2021). Publikasi Kabupaten Kuningan. Retrieved 11 August 2021, from bttps://kuningankab.bps.go.id/publication.

Boedirachminarni, A., Nuraini, I., Widaat., \& Suliswanto, M. S. W. (2017). Strategies for Increasing the Competitiveness of Food Commodities in the Digital Era. International Journal of Economic Research, 14(3): 37-48.

Budiasa, I. W., \& Ambarawati, I. G. A. A. (2014). Community Based AgroTourism as an Innovative Integrated Farming System Development Model Towards Sustainable Agriculture and Tourism in Bali. Journal of the International Society for Southeast Asian Agricultural Sciences, 20(1): 29-40.

Fadilla, A. N., \& Aditya. (2019). Semiotics Analysis of Cibuntu Tourism Village Logo. Bandung Creative Movement International Conference in Creative Industries: $1-4$.

Faidah, A., Hapsari, T. D., \& Juanuar, J. (2016). Analisis Wilayah Komoditas Ubi Kayu dan Kotribusinya Terhadap Sektor Pertanian. JSEP, 9(1): 1-12.

Indrayanti, T., Jamhari., Mulyo, J. H., \& Masyhuri. (2020). The Customer Satisfaction Analysis of Community based Agrotourism in Yogyakarta. Caraka Tani: Journal of Sustainable Agriculture, 35(1): 33-43.

Indrawati, E., Ruchiat R., \& Indrawati, D., \& Febriyani, S. (2020). Integrated Agriculture-Based A Ture-Based Agrotourism Model Wi Ourism Model With Eco-Friendl Eco-Friendly Environmen Y Environmentalism on 
Carik Injem Alism on Carik Injeman Land In Cibodas Village. Journal of Environmental Science and Sustainable Development, 3(1): 177-194.

Institut Pertanian Bogor. (2017). Buku Potensi Wilayah Kabupaten Kuningan Provinsi Jawa Barat. Bogor: KKN-T-FEM IPB.

IPB University. (2021). The Use of Plant Growth Promoting Rhizhobacteria Shortens Harvest Time and Increases Production of Sweet Potatoes. Retrieved 17 August 2021, from https://ipb.ac.id/news/index/2021/03/theuse-of-plant-growth-promoting-rbizhobacteria-shortens-barvest-time-and-increasesproduction-of-sweet-potatoes/37e8a03ffef4bfae45e5f4e616d26399.

Isabhandia, Y. M., \& Setiartiti, L. (2021). Basic Sector Analysis and Development Strategy of Regional Economic Potential in Progo Kulon District 20132017. Journal of Economics Research and Social Sciences, 5(1): 77-87.

Pramanik, P. D., \& Widyastuti, N. (2017). Rural Tourism Destination Strategy through SWOT Analysis in Cibuntu Village-Indonesia. ASEAN Tourism Research Association Conference (ATRC): 27-35.

Prats, G. M., \& Ramirez, A. R. (2018). Analysis of the Behavior of a Regional Economy through the Shift-Share and Location Quotient Techniques. Management Dynamics in the Knowledge Economy, 1.6 (4), 553-568.

Raqib, M., \& Rofiuddin, M. (2018). Determination of Leading Sector Sukoharjo Regency: Location Quotient and Shift Share Esteban Marquillas Approach. International Journal of Economics, Business and Accounting Research (IJEBAR), 2 (2): 107-118.

Robeta, S. (2015). Potensi Wilayah dan Kontribusi Komoditas Ubi Jalar Terhadap Komoditas Tanaman Pangan di Kabupaten Jember. Skripsi. Agribusiness Study Program Faculty of Agriculture University of Jember.

Suarmanayasa, I. N., Susila, G. P. A. J., \& Bagja, I. W. (2018). Determination of Potential Economic Sectors to Support Economic Development Planning. Advances in Economics, Business and Management Research, 69: 69-74 